\title{
DESCARTES, KANT, AND SWINBURNE ON HUMAN SOUL
}

In Are We Bodies or Souls? Richard Swinburne argues in favor of the existence of the human soul. By soul he understands an element different from matter that is the basis of the identity of every human person. Swinburne justifies the thesis about the existence of the human soul with the so-called modal argument. The modal argument comes from Descartes and states that I can think of myself existing without a body. Swinburne believes that his interpretation of Descartes' argument is correct and is not open to objections. Swinburne's book also deals with other issues: the question of the basis of a person's identity in relation to the body, the nature of the causal relationships between the soul and the body and the outside world.

Swinburne's argument from Are We Bodies or Souls? looks as follows:

So the structure of the amended argument is as follows:

first premise: I am a substance which is thinking.

amended second premise: it is conceivable that 'while I am thinking, my body is suddenly destroyed'.

third premise: it is not conceivable that 'I am thinking and I do not exist'. amended lemma: I am a substance which, it is conceivable, can continue to exist while my body is suddenly destroyed.

fourth premise: it is inconceivable that any substance can lose all its parts simultaneously and yet continue to exist.

Stanistaw Judycki, Prof. Dr Hab., Head of the Department of Metaphysics, Philosophy of Religion and Contemporary Philosophy in the Institute of Philosophy, University of Gdańsk; address for correspondence: ul. J. Bażyńskiego 4, 80-952 Gdańsk, Poland; e-mail: s.judycki@ug.edu.pl; ORCID: https://orcid.org/0000-0003-3586-846X. 
amended conclusion: I am a soul, a substance, whose only essential property is the capacity for thought. ${ }^{1}$

In what follows I will analyze two issues from Are We Bodies or Souls? First, I will deal with the "core" of the modal argument, which is the thesis that we can think ourselves without the bodies we have. To my understanding, both Descartes' modal argument and Swinburne's modal argument contain at least four steps: (1) the first step is about being able to think of mentality without any physical basis; (2) the second step is not about a mentality in general, but about a mentality "organized" egologically: it is necessary to show that the human stream of consciousness contains an "I" different from mental states; (3) in the third step it should be proved that this "I" is an absolutely simple being; (4) when the absolute simplicity of the "I" is demonstrated, then the following problem formulated by Kant must be taken into account: even if we assume that this "I" is an absolutely simple intensive magnitude, that is, a magnitude without any parts at all, it does not have to be eternal, as it can still lose its reality.

The second issue that will be raised here will concern Swinburne's thesis that as individual non-material beings (i.e., as souls or persons) we could be born in completely different life circumstances, at different times, of a completely different character. It will be a question whether Swinburne's thesis is not similar to Kant's thesis that in the case of every human person one should distinguish between empirical character and intelligible character.

Both Descartes' argument and Swinburne's argument are modal—both versions of the argument refer to the possibility of something or the impossibility of something. Swinburne states that "it is conceivable that while I am thinking, my body is suddenly destroyed." This formulation could lead to the conclusion that it is about the psychological possibility or impossibility of thinking about something, about the psychological conceivability or inconceivability of something. In reality, however, I believe it is a priori knowledge concerning modal states of affairs. More specifically, it is about intellectual insight into the relationship between simple qualities. These qualities are, on the one hand, mentality, and on the other, materiality, materiality as bodily extension. Such intellectual insight would be part of the metaphysical proof of the existence of the immaterial human soul. C. D. Broad understood this issue in a similar way when he stated:

\footnotetext{
${ }^{1}$ Richard Swinburne, Are We Bodies or Souls? (Oxford: OUP, 2019), 78-79.
} 
The only modern philosopher of importance, so far as I know, who claims to prove immortality of the soul by general metaphysical arguments is Dr M'Taggart. He points quite rightly that all such arguments have an a priori and an empirical part. The a priori part consists in proving that anything which had certain characteristics would necessarily be permanent. The empirical part consists in showing that the human mind has such characteristics... Now I cannot prove that all general metaphysical arguments for human survival must necessarily be invalid. I can only say that all that I am acquainted with seem to be extremely doubtful either in their a priori part or in their empirical part or in both. And they are so much bound up with elaborate metaphysical systems, and have persuaded so few men beside their authors, that I propose to ignore them here. ${ }^{2}$

Broad was skeptical about the possibility of formulating a correct metaphysical proof for the existence of the human soul. When it comes to human survival, Broad favored empirical and ethical arguments. It was different with Aristotle. Without hesitating, Aristotle expressed the thesis about the radical qualitative difference between man having reason and all other living creatures, and argued that the rational human soul enters the embryo from the outside:

It remains, then, that Reason alone enters in, as an additional factor, from outside; and that it alone is divine, because physical activity has nothing whatever to do with the activity of Reason. ${ }^{3}$

The bodily extension, on the one hand, and the mentality on the other, can be treated as two kind of simple qualities, and one may ask if they are necessarily related to each other. Likewise, the spatial extension and the color can be regarded as two simple qualities, and one may ask if they are necessarily related to each other. In the first case, it can be seen that the two qualities are not necessarily related to each other, in the second, that the color necessarily entails extension: there can be no objects that are colored but not have extension. This kind of intellectual insight is a priori insight in the sense that it results in necessary and strictly general knowledge. As I believe, the first step of Descartes and Swinburne's modal argument should be interpreted as an a priori insight into the necessity or contingency of connection between human mentality and human body. Descartes, too, sought to attain this kind of a priori insight:

\footnotetext{
${ }^{2}$ C. D. Broad, Mind and its Place in Nature (London: Kegan Paul, 1925), 485-86.

${ }^{3}$ Aristotle, Generation of Animals, trans. A. L. Peck (London: Heinemann, 1940), 736 b.
} 
Now it is plain I am not the assemblage of members called human body; I am not a thin and penetrating air diffused through all these members, or wind, or flame, or vapour, or breath, or any of all the things I can imagine; for I suppose that all these were not, and, without changing the supposition, I find that I still feel assured of my existence. $^{4}$

The modal arguments of Descartes and Swinburne are therefore examples of a priori insights into the essential features of the studied objects, examples of eidetic intuiting. The concept of eidetic intuition goes back to Aristotle and his concept of induction (epagogé) as an intuitive insight into the relations between universals. Herbert Spiegelberg, historian of the phenomenological movement, stated that:

Essential relations between several essences are established by the procedure of imaginative variation too. Keeping one essence constant we try to combine it with various other essences, leaving off some of its associates, substituting others for them, or adding essences not hitherto encountered together with them. Wherever the omission or substitution of associated essences proves impossible, we diagnose an essential necessity; where they prove at least compatible with one another, an essential possibility; where they repel each other, an essential impossibility. The stock example of such relationship is that between essences of color and extension. ${ }^{5}$

The results of eidetic intuition should be interpreted as cases of morphological a priori: the object of eidetic intuition is the relationship between qualities that is directly present to consciousness. Morphological a priori and morphological essences should be contrasted with knowledge of "hidden" essences. ${ }^{6}$ Natural science aims to reveal "hidden" essences in an empirical way. It should also be noted that knowledge about "hidden" essences would not be possible if on the morphological level, that is, on the level of direct experience, human mind was not able to grasp

\footnotetext{
${ }^{4}$ René Descartes, The Meditations and Selections from the Principles of René Descartes, trans. John Veitch (Chicago: Open Court, 1903), 33.

${ }^{5}$ Herbert SPIEgelberg, The Phenomenological Movement. A Historical Introduction, 3rd ed. (The Hague: Nijhoff, 1982), 701. Spiegelberg was aware of the objections to this kind of interpretation of synthetic a priori knowledge: "What has aroused much more suspicion than the intuiting, analyzing, and describing phenomena is the phenomenology of general essences, usually called Wesnesschau or eidetic intuition. Not only outsiders and antagonists of the Phenomenological Movement but some of its forerunners, like Brentano or Stumpf, and sympathizers, like the gestaltists, betray a certain irony whenever this procedure is mentioned. Not only was it suspected as a new type of mysticism. Equally serious was the misinterpretation according to which it implied a commitment to a Platonic 'realism'" (p. 696).

${ }^{6}$ The distinction between morphological essences and "hidden" essences is presented by Joseph M. BocheŃSKI in his The Methods of Contemporary Thought (Dordrecht: Reidl, 1965), 23-29.
} 
different kinds of necessary relationships. The rejection of the possibility of direct apprehension of the necessary and strictly general connections between morphological essences and their components must lead to the negation of the validity of any kind of inference, including the validity of inferences made within the natural sciences. The rejection of a priori morphological knowledge must therefore lead to global skepticism. The ultimate basis of elementary logical principles, and hence the basis of the notion of logical possibility, is knowledge concerning the relationship between morphological essences. The principles of logic can either be considered so basic that they require no further explanation, or it can be argued that they are based on a priori morphological knowledge. ${ }^{7}$

Even if we assume that the mental domain arose from the physical and organic domains (emergentism), this step of the modal argument will still be valid, that is, it can still be argued that the mental realm is not necessarily connected with the physical and organic realms. If we were to hypothesize that the colors of physical things came about as a result of changes taking place in the shape of those things, the necessity would still apply that whatever is colored has a shape; as well as that whatever has a shape must have some color. Such a hypothesis would be a purely speculative genetic hypothesis, since we can in no way imagine things having only shapes. We know from our everyday experience a bodily extension completely devoid of mentality. While we do not know a mentality that exists independently of any physical basis, there is no contradiction in the existence of a mentality without a physical basis, and so such existence is logically possible. It can therefore be argued that it is a necessary truth that mentality and bodily extension are not necessarily related to each other.

However, it might be noted that also water and $\mathrm{H}_{2} \mathrm{O}$ are not necessarily related to each other: one might think that $\mathrm{H}_{2} \mathrm{O}$ would induce a different sensory experience than that of a colorless and liquid substance, and one might think that in the future our science would discover that water as colorless and a liquid substance, has a different chemical composition than what we recognize now. The unnecessary

\footnotetext{
7 "My own guess is that the truths of logic we are speaking of are so basic that the notion of explanation collapses when we try to 'explain' why they are true. I do not mean that there is something 'unexplainable' here; there is simply no room for explanation of what is presupposed by every explanatory activity, and that goes for philosophical as well as scientific explanations" (Hilary PutNam, Analyticity and Apriority: Beyond Wittgenstein and Quine, in Philosophical Papers, vol. 3, Realism and Reason, ed. Hilary Putnam [Cambridge: CUP, 1983], 138). I assume that there are four types of a priori synthetic propositions: (1) logical principles, (2) mathematical propositions, (3) propositions such as "Nothing can be red and green all over or "Whatever has color has shape," (4) moral propositions (see, for example, Panayot Butchvarov, The Concept of Knowledge [Evanston, IL: Northwestern University Press, 1970], 141).
} 
connection between water and $\mathrm{H}_{2} \mathrm{O}$, however, is entirely different from the unnecessary connection between he mental domain to bodily extension. The contingent relationship between $\mathrm{H}_{2} \mathrm{O}$ and water is valid only within our physical world, while the contingent relationship between the mental realm and the body applies to all possible physical worlds.

It can be argued that all human mental states are egologically organized: they always refer to one pole or center. We name this pole or center by the word 'I'. The argument for the existence of "I" as something different from mental states refers to inner experience (introspection), but some philosophers, e.g., D. Hume, have argued that inner experience informs us only about the stream of various conscious mental states, but it gives us no information about the "I" separate from these states. In Swinburne's argument, this issue is not addressed. Swinburne's argument contains only the first step of the four mentioned above, namely, an a priori insight into the unnecessary connection between the mental and the physical domain.

In Are We Bodies or Souls? there is no consideration of the difference between a stream of consciousness and a subject distinct from it. For a long time, however, various types of reduction of the "I" phenomenon to something else have been tried. It has been argued, for example, that the "I" phenomenon arises as a result of the existence of a uniform connection between the individual components of the stream of consciousness. The question of the separateness of "I" from the conscious mental states themselves should be considered in the argument of the existence of the human soul, for the soul, whatever it may be, has never been identified with the mental states of a particular person.

The second step of Descartes' and Swinburne's argument would therefore have to be to show that it is impossible for there to be a stream of conscious mental states without subject of those states. Regarding this point, one can imagine the following argumentation. First, the stream of human mental states is "saturated" semantically. This is a fact of fully developed human consciousness. Second, if the stream of conscious mental states is "saturated" semantically, it must also be egologically organized. The subject of the stream of conscious semantic states cannot identify with any of these states, cannot be their sum, mixture, etc. It could therefore be argued that it is logically impossible for there to be a stream of conscious semantic states, and at the same time there is no "I" capable of some understanding of them. If there were a stream of conscious semantic states, and no subject capable of understanding them, we would have to do with something as impossible as a car without a driver, be it a human driver or a computer driver.

When we assume that the phenomenon of "I" is not an illusion, it should be shown that "I" has the characteristics of a substance. It should be remembered that the persistence of "I" in the changes of the representations it possesses does not 
imply that it can continue without these representations. Limited duration in time under certain circumstances does not entitle to the conclusion that the "I" will last for an unlimited time. ${ }^{8}$

The traditional understanding of substance attributed to it two characteristics: being the subject of change and the persistence in changes. In the third step of the proof of the existence of the human soul, it should be shown that "I" not only persists in changes and is the subject of these changes, but also that it is something absolutely simple. It would follow from the absolute simplicity of "I" that "I" cannot disintegrate, so that it can last for an unlimited time.

However, even when we assume that "I" possesses the characteristics of absolute simplicity, the following problem raised by Kant still remains of importance:

The identity of the consciousness of myself at different times is therefore only a formal condition of my thoughts and their coherence, and in no way proves the numerical identity of my subject. Despite the logical identity of the 'I', such a change may have occurred in it as does not allow of the retention of its identity, and yet we may ascribe to it the same sounding 'I', which in every different state, even in one involving change of the [thinking] subject, might still retain the thought of the preceding subject and so hand it over to the subsequent subject. ${ }^{9}$

This is a difficult problem. In Swinburne's book it is not taken up at all. It would be possible to answer Kant that it is impossible, logically impossible, for thinking to occur in many substances. For example, Bernard Bolzano thought so. ${ }^{10}$

8 "Hier sollte die Unsterblichkeit erwiesen werden, also in aller Ausdrücklichkeit die ewige Dauer in der Zeit. Kant hat in seinem Paralogismus der 'Substantialität' klar den Punkt aufgezeigt, in dem Fehlschluss liegt: er liegt in der Auffassung des Ich als absolut Beharrendes. Ohne Zweifel gibt es eine Beharrung des Ich im Wechsel der Vorstellungen, nämlich solange der Mensch lebt und Vorstellungen hat. Daraus folgt aber nicht, dass das Ich ohne den Wechsel der Vorstellungen, also ohne Wahrnehmungen und empirisches Erleben, fortbestehen könne. Das aber ist es, was man beweisen wollte. Aus begrenzter Dauer unter bestimmten Verhältnissen lässt sich auf unbegrenzte Fortdauer unter gänzlich veränderten Verhältnissen, also auch auf Substantialität, in keinem Falle schließen" (Nicolai Hartmann, Philosophie der Natur. Abriss der speziellen Kategorienlehre [Berlin: De Gruyter, 1950], 276-77).

${ }^{9}$ Norman Kemp Smith, Immanuel Kant's Critique of Pure Reason (London: Macmillan, 1929), A 363.

10 "Auf welche Art wir also immer versuchen wollen, den Satz zu rechtfertigen, dass unser Denken, Empfinden, Wünschen und Wollen in einem aus mehreren Substanzen zusammengesetzten Ganzen vor sich gehe, wir stoßen jedesmal auf einen Widerspruch. Es ist somit erwiesen, dass unsere Seele ... nur eine einfache Substanz sei" (Bernard Bolzano, Athanasia oder die Gründe für die Unsterblichkeit der Seele, in Bernard Bolzano. Ausgewählte Schriften, ed. Eduard Winter [Berlin: Union, 1976], 244). Bolzano referred to the fact that the components of our body and brain are constantly exchanged, and hence he concluded that the identity of our "I" cannot be based on something physical. 
Kant realized that the simplicity of "I" was an obvious and immediate given to consciousness. However, he also realized that the hypothesis of many numerically different substances being subjects of thought is difficult to accept. Therefore, he claimed that even if "I" were something absolutely simple and in this sense something immaterial, it would not follow that this "I" would last forever after the disintegration of the body:

Even if we admit the simple nature of soul, namely, that it contains no manifold of constituents external to one another, and therefore no extensive quantity, we yet cannot deny, any more than to any other existence, intensive quantity, that is, a degree of reality in respect of all its faculties, nay, in respect of all that constitutes its existence, and that this degree of reality may diminish through all the infinitely many smaller degrees. In this manner the supposed substance ... may changed into nothing, not indeed be dessolution, but by gradual loss (remissio) of its powers, and so, if I may be permitted the use of the term, by elanguescence. ${ }^{11}$

One could reply to Kant that an immaterial soul cannot lose its reality through the gradual loss of its strength, through this "elanguescence," because all the soul's powers are as simple as the soul itself. So there is no possibility for the soul to "leap from being to nothingness." Perhaps Kant meant something similar to the color fading of fall leaves, but this is only a metaphor. The discussion of the "elanguescence" hypothesis does not appear in Swinburne's book, and it would have to be the fourth step in his proof of the existence of the human soul.

Swinburne's second thesis, which I would like to address here, is that

it cannot be necessary for the identity of any person who has lived a normal-length life that he or she had any of the later mental events of their life; it would still have been me who continued to live if I had been adopted by surrogate parents immediately after my birth and had had a totally different sequence of mental events thereafter. So if any mental events are necessary for the identity of some person, it must be the very earliest ones. But it does seem implausible to suppose that it wouldn't have been me who came out of my mother's womb at a certain time just because the foetus which turned into the baby who did emerge had as its earliest mental events qualitatively different aches and pains from the ones which I had. Having mental events of just those kinds cannot be necessary for that foetus to be the earliest stage of me. Hence the identity of a particular person is not constituted by having had any particular mental properties at past times. It follows

${ }^{11}$ Kemp Sмiтh, Immanuel Kant's Critique of Pure Reason, B 414. 
that persons, and so their essential parts, their souls, have what philosophers call 'thisness' (= haecceity), which makes them and so their soul the particular ones they are. ${ }^{12}$

To this Swinburne adds that

in the case of ordinary medium-sized physical substances, the thisness of a substance (if it has thisness) plausibly consists in the chunk of matter of which it is made having thisness. But if a soul has thisness, that cannot consist in it being made of different matter (since souls are not physical substances), nor can it consist of being made of some mental stuff, since any stuff is (it is logically possible) divisible; and (as I argued in Chapter 3), persons and therefore their souls are indivisible. So if the soul has thisness, it must be just a brute fact that it does have thisness. ${ }^{13}$

If people (souls) have "thisness," then, according to Swinburne, they do not identify with their life story, nor with their character, nor with the features that are presented to them within their self-consciousness. Swinburne also argues that the meanings of the words persons use in relation to themselves are private informative designators: only I know what the word "pain" means to me, etc. These theses must lead to two conclusions: (1) my soul is unknown to other people through interpersonal communication; (2) individual souls do not know themselves through inner experience. In inner experience, we only get to know ourselves by noticing our own current states of consciousness, our own character traits, etc. However, according to Swinburne, each soul is different from its own mental states and properties. From here it must follow that souls do not know themselves (almost) at all, do not know what or who they are. Kant formulates a similar thesis:

Even the inner and sensible intuition of our mind (as the object of consciousness) which is represented as being determined by the succession of different states in time, is not the self proper, as it exists in itself - that is, is not the transcendental subject—but only an appearance that has been given to the sensibility of this, to us unknown, being. ${ }^{14}$

Perhaps Swinburne would answer that each soul knows itself by the preconceptual feeling or that the self-knowledge of each soul is knowledge by acquaintance, but not knowledge by description.

\footnotetext{
${ }^{12}$ Swinburne, Are We Bodies or Souls? 109.

${ }^{13}$ Ibid., 111.

${ }^{14}$ Kemp Smith, Immanuel Kant's Critique of Pure Reason, A 492.
} 
As is known, Kant officially argued that the question of the existence of the soul was theoretically undecidable. However, the concept of the soul returned in his attempts to overcome the so-called third antinomy, that is, the antinomy of freedom, returned in the form of the concept of intelligible character. It is the intelligible character that is responsible for the decisions we make, and therefore also for our behavior, so it is the intelligible character that affects our brain and our body. Like Kant, Swinburne also claims that the soul has a causal effect on the brain and the body:

I argued that it follows from the principle of credulity that because it seems to us so strongly that mental events often do cause brain events, it is rational to believe that this is the case-in the absence of significant counter-evidence. ${ }^{15}$

If the soul has a causal effect on the body, but does not identify itself with any of its mental properties, and thus knows itself only through knowledge by acquaintance, then when someone, for example, maliciously lies (Kant's example), we must assume that the cause of this lie is a being which we hardly know at all:

Thus in our judgments in regard to the causality of free actions, we can get as far as intelligible cause, but not beyond it. We can know that it is free, that is, that it is determined independently of sensibility, and that in this way it may be the sensibly unconditioned condition of appearances. But to explain why in the given circumstances the intelligible character should give just these appearances and this empirical character transcends all the powers of reason. ${ }^{16}$

Both Kant's thesis about the existence of an intelligible character and Swinburne's thesis that the soul has "thisness" must lead to the consequence that man is only a phenomenon. According to Kant, however, the relationship between the intelligent and the empirical character is complicated. This complication is evidenced by the following statement by Kant:

The real morality of actions, their merit or guilt, even that of our own conduct, thus remains hidden from us. Our imputations can refer only to empirical character. How much of this character is ascribable to the pure effect of freedom, how much to mere nature, that is, to the faults of temperament for which is no responsibility, or to its happy constitution (merito fortunae), can never be determined; and upon it therefore no perfectly just judgments can be passed. ${ }^{17}$

\footnotetext{
${ }^{15}$ SwinbuRne, Are We Bodies or Souls, 131.

${ }^{16}$ Keмp Sмiтн, Immanuel Kant's Critique of Pure Reason, 557/B585.

${ }^{17}$ Ibid., A 552/B580.
} 
It must therefore be assumed that both according to Kant and Swinburne, human persons belong to two worlds simultaneously, to the noumenal world and to the phenomenal world. There are causal relationships between these worlds. According to Kant, the existence of an intelligible character guarantees that free will is not an appearance. The intelligible character is causa noumenon. Swinburne also has to claim that the soul, as an immaterial being and as a being having "thisness," belongs to a world other than that which is given to its senses. So also the "thisness" that Swinburne writes about must be regarded as a causa noumenon, not a causa phenomenon.

The soul that has "thisness" does not identify itself with any of its features that are given to it in its own inner experience, nor does its nature depend on the circumstances of life. The consequence of this would have to be, for example, that my "thisness" could appear in ancient Egypt. From this it must follow that we are a mystery to ourselves. There are also great complications in moral matters. For example, there is a problem whether I am not subject to some kind of predestination because of my "thisness," at least in terms of the times in which I live or the empirical character I have received.

Swinburne's dualism is referred to as Cartesian dualism and is often opposed to Thomistic hylomorphic dualism, but both of these dualisms, I believe, must solve at least the problems listed above in order to be able to prove at all that there is such a thing as an immaterial human soul. Only then can one ask which dualism is better and in what respect. Both dualisms also have to deal with the consequence that, as immaterial souls, we live simultaneously in two worlds, that is, in a spiritual world we do not know, and in "our" world that we somehow know. I believe that this kind of question cannot be resolved without appealing to God, to His wisdom and goodness, and to His plans for individuals.

\section{BIBLIOGRAPHY}

Aristotle. Generation of Animals. Translated by A. L. Peck. London: Heinemann, 1940.

BocheŃsKi, Joseph M. The Methods of Contemporary Thought. Dordrecht: Reidl, 1965.

Bolzano, Bernard. Athanasia oder die Gründe für die Unsterblichkeit der Seele. In Bernard Bolzano. Ausgewählte Schriften, edited by Eduard Winter. Berlin: Union, 1976.

BroAd, C. D. Mind and its Place in Nature. London: Kegan Paul, 1925.

Butchvarov, Panayot. The Concept of Knowledge. Evanston, IL: Northwestern University Press, 1970.

Descartes, René. The Meditations and Selections from the Principles of René Descartes. Translated by John Veitch. Chicago: Open Court, 1903.

Hartmann, Nicolai. Philosophie der Natur. Abriss der speziellen Kategorienlehre. Berlin: De Gruyter, 1950.

Kemp Sмiтh, Norman. Immanuel Kant's Critique of Pure Reason. London: Macmillan, 1929. 
Putnam, Hilary. "Analyticity and Apriority: Beyond Wittgenstein and Quine." In Philosophical Papers, vol. 3, Realism and Reason, edited by Hilary Putnam, 113-38. Cambridge: CUP, 1983.

Spiegelberg, Herbert. The Phenomenological Movement. A Historical Introduction. 3rd ed. The Hague: Nijhoff, 1982.

Swinburne, Richard. Are We Bodies or Souls? Oxford: OUP, 2019.

DESCARTES, KANT, AND SWINBURNE ON HUMAN SOUL

\section{Su m mary}

This paper addresses two issues in Richard Swinburne's book Are We Bodies or Souls? I interpret Swinburne's modal argument as an example of a priori synthetic knowledge. Swinburne's thesis that every person possesses "thisness" is compared with Kant's distinction between the empirical character and the intelligible character.

Keywords: soul; synthetic a priori knowledge; Kant; empirical and intelligible character. 